GLAUCO COSTA LEITE

\title{
A TUTELA JURÍDICA DAS PROPOSIÇÕES ELEITORAIS NO POLO DO PODER EXECUTIVO
}

\author{
Tese de Doutorado \\ Regime de Dupla Titulação \\ Orientadoras: Profa. Dra. MONICA HERMAN SALEM CAGGIANO (USP) \\ Profa. Dra. PILAR JIMÉNEZ TELLO (USAL)
}

Faculdade de Direito da Universidade de São Paulo Facultad de Derecho de la Universidad de Salamanca 



\author{
GLAUCO COSTA LEITE
}

\title{
A TUTELA JURÍDICA DAS PROPOSIÇÕES ELEITORAIS NO POLO DO PODER EXECUTIVO
}

Tese de Doutorado apresentada a Banca Examinadora do Programa de Pós-Graduação em Direito, da Faculdade de Direito da Universidade de São Paulo, em regime de dupla titulação com a Universidade de Salamanca, na área de Concentração Direito de Estado, sob co-orientação da Prof. ${ }^{a}$ Dr. $^{a}$ Monica Herman Salem Caggiano (USP) e Prof. ${ }^{a}$ Dr. ${ }^{a}$ Pílar Jiménez Tello (USAL).

\section{SÃO PAULO}


Catalogaçáo da Publicaçáo

Serviço de Biblioteca e Documentaçăo

Faculdade de Direito da Universidade de Såo Paulo

Costa Leite, Glauco

A TUTELA JURIDICA DAS PROPOSICCOES ELEITORAIS NO

POLO DO PODER EXECUTIVo ; Glauco Costa Leite :

orientadora Monica Herman Salem Caggiano .. Săo

Paulo, 2019.

236

Tese (Doutorado - Programa de Pós-Graduaça em

Direito do Estado) - Faculdade de Direito,

Universidade de Sằ Paulo, 2019.

1. Direito do Estado - 2. Eleiçoes. 3. Democracia.

I. Herman Salem Caggiano, Monica, orient, II. Titulo. 


\author{
GLAUCO COSTA LEITE
}

\title{
A TUTELA JURÍDICA DAS PROPOSIÇÕES ELEITORAIS NO POLO DO PODER EXECUTIVO
}

Tese apresentada ao Programa de PósGraduação em Direito de Estado, como requisito para obtenção do título de Doutor em Direito do Estado.

Orientadoras: Prof. $^{\text {a }}$ Dr. $^{\text {a }}$ Monica Herman Salem Caggiano. 

À minha filha Sofia que me fez descobrir uma porta oculta em meu coração. 



\section{AGRADECIMENTOS}

Em primeiro lugar quero agradecer a Deus por me permitir participar de um programa de doutoramento tão importante e me dar força nos momentos de dificuldade. É motivo de inestimável orgulho fazer parte do corpo dicente de pós-gradução de duas das universidades mais renomadas do mundo: a Universidade de São Paulo (USP) e a Universidade de Salamanca (USAL). Nem em meus maiores sonhos pude imaginar chegar até aqui. Os três anos percorridos no programa somente se mostraram possíveis graças à contribuição de diversas pessoas. Mesmo certo de que não me lembrarei de todos, agradeço em especial:

À minha esposa Cibele, pelo incondicional apoio em todas as horas, e por sempre compreender minhas ausências, estimulando a vida acadêmica.

À minha filha Sofia, responsável pelo maior presente recebido em vida, a paternidade.

Aos meus pais, pelo exemplo de dedicação, amor, perseverança e superação das dificuldades.

Às minhas queridas professoras orientadoras, Professora Monica Herman Salem Caggiano (USP), de quem tenho a honra de ser novamente orientado, e à Professora Pílar Jímenez Tello (USAL). Além das valorosas orientações, ambas se tornaram grande amigas. A vida acadêmica trilhada por ambas reflete a forma como incansavelmente lutam pela defesa do direito, do ensino e de seus alunos.

Ao Professor Doutor Claudio Lembo, que desde o programa de mestrado me levou a conhecer o sábio e culto mestre que era ocultado pelo hábil representante político.

A todos os Professores da Universidade de São Paulo e da Universidade de Salamanca com quem tive a oportunidade de conviver durante todo o período de pesquisa, especialmente: Manoel Gonçalves Ferreira Filho (USP), José Maurício Conti (USP), Rodrigo Pagani de Souza (USP), Marcos Augusto Perez (USP), Fernanda Dias Menezes de Almeida (USP) e Ricardo Rivero Ortega (USAL).

Aos Professores Doutores egressos do programa de pós-gradução Bruno César Lorecini e Alesssandro Soares, pelas orientações de pesquisa. 
Aos colegas do programa de pós-graduação Thalita Abdalla Aris, André Xerez, Nicanor Barry Komata, Alessandra Salles, e ao também amigo de infância, Fernando Fabiani Capano.

Aos colegas magistrados do Poder Judiciário do Estado de São Paulo, especialmente àqueles com quem pude refletir sobre o tema objeto desta pesquisa, o Professor Doutor José Wellington Bezerra da Costa Neto, minha referência como pesquisador, magistrado, amigo e irmão e o Dr. Gustavo Sampaio Correa, amigo de todas as horas, irmão e incansável magistrado.

À Natalia Tammone que, mais uma vez, aceita revisar minha pesquisa, além de apresentar verdadeiras lições de História.

Registro também meus agradecimentos a todos os funcionários das bibliotecas da Universidade de São Paulo e da Universidade de Salamanca, bem como de outras pessoas que, de uma forma ou de outra, me auxiliaram com a presente pesquisa: Camila Tammone, Ana Cristina Vieira Garcia Queiroz, Vagner Bessa, todos os funcionários da $3^{\circ}$ Vara Cível da Comarca de Mauá, minhas estagiárias Beatriz Martins, Brenda Trindade e Bárbara Levorato.

Por fim, a todas as crianças e adolescentes abrigados em Mauá, Ribeirão Pires e Rio Grande da Serra, cujos sorrisos e resiliência inspiram a busca de um mundo mais igual, em especial, Marta, Evelyn, Maria Roberta, Letícia, Endrew, Pablo, Guilherme, Laysla, Veronica, Ericka e Hemilly. 
"La libertad Sancho es uno de los mas preciosos dones que a los hombres dieron los cielos, con ella no pueden igualarse los tesoros que encierra la tierra ni el mar encumbre".

Don Quijote de la Mancha 



\section{RESUMO}

A pesquisa analisa as propostas eleitorais formuladas durante a campanha e a ausência de instrumentos jurídicos aptos a conferir algum grau de eficácia ao cumprimento das proposições. Trata-se de investigação que parte da verificação da existência de crise democrática e de representação política global que reclamam instrumentos que reaproximem o cidadão da política. Analisam-se os diferentes tipos de propostas eleitorais no Brasil e em sistemas alienígenas. Sugere-se a criação de dois instrumentos de controle das propostas eleitorais como forma de combate à demagogia eleitoral e para promover a valorização das eleições. Em sede administrativa, o controle por meio de órgão criado exclusivamente para tal finalidade, refletindo o dever de tutela do Estado pela veracidade das informações relacionadas à efetividade da administração. Em âmbito judicial, sugerese a contratualização de algumas propostas realizadas pelos candidatos com potencial para, em limitadas hipóteses, permitir a tutela jurisdicional coletiva das propostas eleitorais, autorizando-se o Poder Judiciário a conceder a tutela específica correspondente ao objeto da proposta. Estes instrumentos podem conferir maior transparência e coercibilidade no cotejamento entre as propostas eleitorais formuladas e sua efetiva implementação, bem como inserir maior grau de responsabilidade na escolha cidadã.

Palavras-chave: PROPOSTAS ELEITORAIS; REPRESENTAÇÃO POLÍTICA; EFICÁCIA; CONTROLE ADMINISTRATIVO; TUTELA JUDICIAL COLETIVA 


\begin{abstract}
The research analyzes the electoral proposals formulated during the campaign and the absence of legal instruments capable of conferring any degree of effectiveness to the fulfillment of the propositions. This research is based on the verification of the existence of a democratic crisis and a global political representation crisis that demand instruments that bring citizens closer to politics. The different types of electoral proposals in Brazil and in alien systems are analyzed. It is suggested the creation of two instruments to control electoral proposals as a way to combat electoral demagogy and to promote the valorization of elections. In administrative area, it is suggested the control through an institution created exclusively for such purpose, reflecting the State's duty to protect the truthfulness of information related to the effectiveness of the administration. At the judicial level, it is suggested to contract some proposals made by candidates with the potential to, under limited circumstances, allow collective judicial protection of electoral proposals, authorizing the Judiciary to grant specific protection corresponding to the object of the proposal. These instruments can provide greater transparency and coercibility in the comparison between the formulated electoral proposals and their effective implementation, as well as insert greater degree of responsibility in the citizen choice.
\end{abstract}

Keywords: ELECTION PROPOSALS; POLICY REPRESENTATION; EFFICIENCY; ADMINISTRATIVE CONTROL; COLLECTIVE COURT JUDICIAL 


\section{RESUMEN}

La investigación analiza las propuestas electorales formuladas durante la campaña y la ausencia de instrumentos legales capaces de conferir algún grado de efectividad al cumplimiento de las propuestas. Esta investigación se basa en la verificación de la existencia de una crisis democrática y una crisis de representación política global que exigen instrumentos que acerquen a los ciudadanos a la política. Se analizan los diferentes tipos de propuestas electorales en Brasil y en sistemas extranjeros. Se sugiere la creación de dos instrumentos para controlar las propuestas electorales, como una forma de combatir la demagogia electoral y para promover la valorización de las elecciones. En el área administrativa, se sugiere el control a través de una institución creada exclusivamente para tal fin, reflejando el deber del Estado de proteger la veracidad de la información relacionada con la efectividad de la administración. A nivel judicial, se sugiere contratar algunas propuestas hechas por candidatos con el potencial de, bajo circunstancias limitadas, permitir la protección judicial colectiva de las propuestas electorales, autorizando al Poder Judicial a otorgar la protección específica correspondiente al objeto de la propuesta. Estos instrumentos pueden proporcionar una mayor transparencia y coercibilidad en la comparación entre las propuestas electorales formuladas y su implementación efectiva, así como insertar un mayor grado de responsabilidad en la elección de los ciudadanos.

Palabras clave: PROPUESTAS DE ELECCIÓN; REPRESENTACIÓN DE POLÍTICAS; EFICIENCIA; CONTROL ADMINISTRATIVO; CORTE COLECTIVA JUDICIAL 



\section{SUMÁRIO}

INTRODUÇÃO

PARTE I - FUNDAMENTOS PARA ANÁLISE DA DEMOCRACIA, REPRESENTAÇÃO POLÍTICA E PROPOSTAS ELEITORAIS .................................29

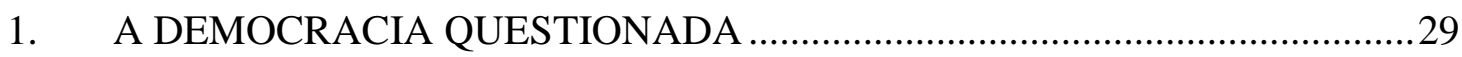

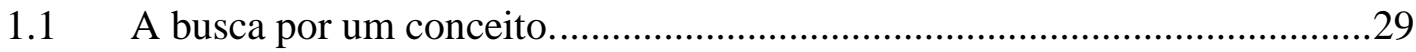

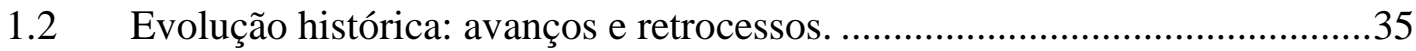

1.3 Características do regime democrático contemporâneo.................................41

1.4 Desigualdade democrática: a democracia aparente. ..................................44

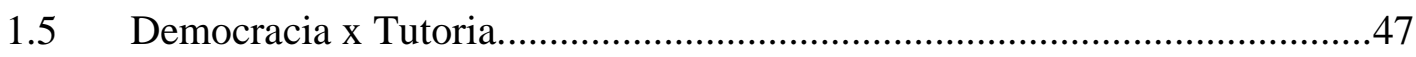

1.6 Avaliação da qualidade democrática........................................................50

1.7 Desafios democráticos na contemporaneidade. .........................................54

2. VINCULO POLÍTICO-ELEITORAL E A INSUFICIÊNCIA DOS

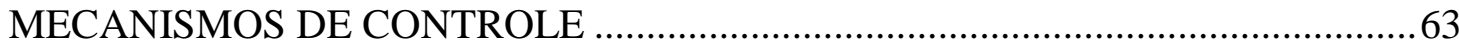

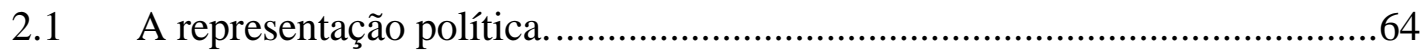

2.2 Natureza jurídica do vínculo político-eleitoral: mandato imperativo $\mathrm{x}$

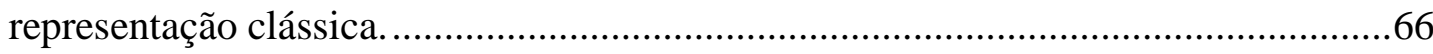

2.3 Tentativas de reaproximação com o mandato imperativo. ...........................72

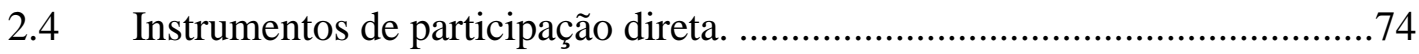

2.5 Confiança política e mecanismos de controle da representação....................80

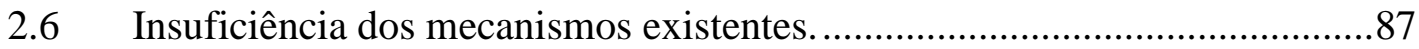

2.7 O Constitucionalismo Aspiracional e a democracia responsiva. ..................88

2.8 O Poder Judiciário e o controle político da representação............................92

3. PROPOSIÇÕES ELEITORAIS E SUA RELEVÂNCIA NAS

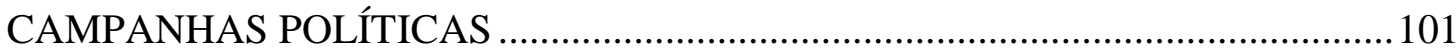

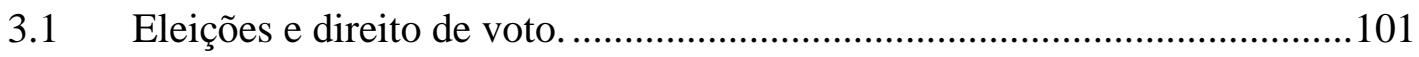

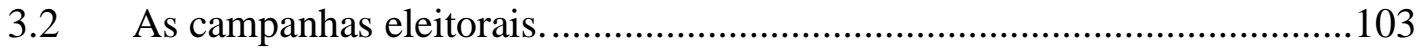

3.3 O processo de escolha de candidatos pelo eleitorado. ................................109

3.4 As proposições eleitorais e a promessa do paraíso. ....................................115

3.5 Natureza jurídica das proposições eleitorais...............................................119 
3.6 As modalidades de proposições eleitorais.

3.7 Da falta de controle jurídico sobre as propostas eleitorais e a busca da eficiência.

3.8 As proposições eleitorais no direito comparado.

3.9 Da necessidade de caráter cogente às propostas.

PARTE II - PROPOSTAS DE CONTROLE ADMINISTRATIVO E JUDICIAL

DAS PROPOSIÇÕES ELEITORAIS

4. CONTROLE ADMINISTRATIVO DAS PROPOSTAS ELEITORAIS

4.1 Eficiência administrativa e avaliação da execução do plano de governo e demais propostas eleitorais.

4.2 O controle das políticas públicas e a parametrização estatística................ 150

4.3 Entidades privadas de controle de políticas públicas................................ 153

4.4 Agências governamentais de análise de estatísticas................................. 155

4.5 O Estado e o dever de tutela da veracidade das informações públicas. ..... 159

4.6 Delineamentos para a criacao de órgão verificador do cumprimento de propostas eleitorais.

4.7 Do processo de análise das propostas e da emissão de parecer acerca do cumprimento.

4.8 Possibilidades de escusa ao cumprimento da proposição.

4.8.1 Cumprimento de proposta que demande aprovação de projeto de lei ou emenda constitucional.

4.8.2 Proposta que depende de recursos financeiros advindos de outra esfera... 177

4.8.3 Cumprimento de proposta obstado por decisão judicial.

4.8.4 Instrumento de democracia direta que altere a conteúdo da proposta........ 178

4.8.5 "Fato do príncipe", teoria da imprevisão e fatos imprevistos. .................... 180

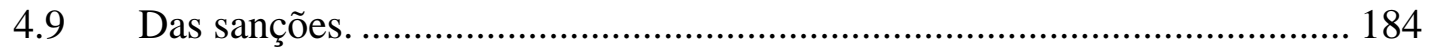

4.10 Da revisão do mérito dos pareceres pelo Poder Judiciário......................... 185

5. SISTEMA DE TUTELAS DAS PROPOSTAS ELEITORAIS GERADORAS DE DIREITO COLETIVO - causas de inelegibilidade, os “contratos políticos" e a cláusula "elegível a direito".

5.1 Causa de inelegibilidade - promessa de cumprimento integral de mandato.

5.2 "Contratos políticos" sob a perspectiva da democracia contratual.

5.3 Da revisão do "contrato político". 
$5.4 \quad$ Tutela jurisdicional coletiva das propostas eleitorais. ..............................200

5.5 Do Procedimento de tutela judicial das propostas eleitorais......................209

5.5.1 Do registro do "contrato político" e da avaliação preliminar. ....................209

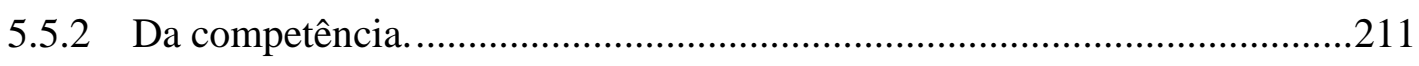

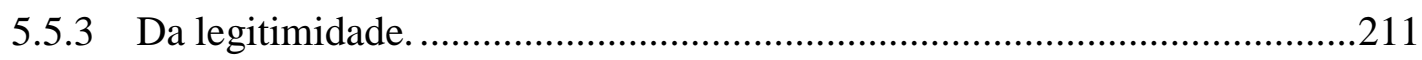

5.5.4 Do processo judicial nos contratos com “cláusulas elegíveis a direito”.....213

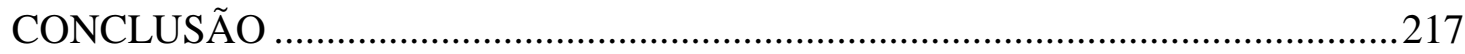

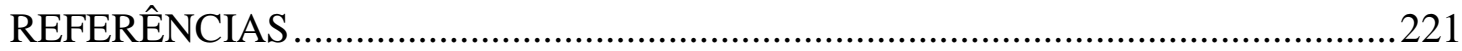

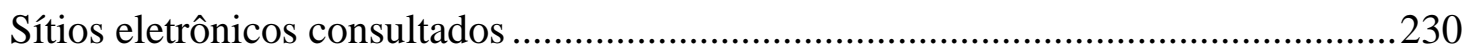

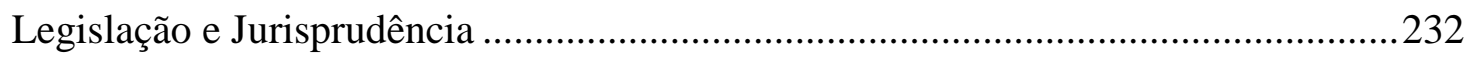

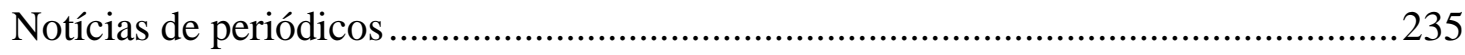





\section{INTRODUÇÃO}

Nos últimos anos a democracia tem sido bastante criticada por não permitir de forma efetiva a participação social, bem como por não ser identificada como instrumento que permite às nações promover transformação social, com redução de desigualdades, distribuição de riquezas, enfim, por não fomentar um aprimoramento social qualitativo. Essa insatisfação, que ocorre não apenas no Brasil, mas em diversos países, tem diminuído o apreço de diversos setores da sociedade pela democracia, levando a questionamentos se a promoção da igualdade social encontra-se ou não dentro dos limites da democracia. Independente da resposta a esta questão o regime democrático comporta aprimoramento, de forma a torná-lo mais racional, efetivo e detentor de maior legitimidade.

Discutir o declínio da aceitação da democracia representa novamente flertar com regimes autoritários. O término da Primeira Guerra pareceu a vitória do princípio democrático, com o fim do Reich alemão. Porém, anos depois, o fascismo na Itália e o nacional-socialismo na Alemanha fortaleceram uma nova forma política, a ditadura. Mesmo com a queda destes regimes após a Segunda Guerra essas filosofias não desapareceram e ainda permanecem latentes, aguardando a possibilidade de ressurgimento a vista de um fraquejar democrático.

Neste cenário, impõe-se uma revisitação à teoria da democracia buscando restaurar sua confiabilidade e uma reaproximação entre o cidadão e a política, por meio de mecanismos jurídicos que possam incrementar o regime democrático. É nesta linha que surgiram os mecanismos de exercício direto da democracia.

A presente pesquisa terá por recorte o momento eleitoral no qual os candidatos apresentam suas propostas aos eleitores visando garantir o voto e, por conseguinte, a legitimidade de representação no pólo do Poder Executivo. É neste momento que o candidato e seu partido, juntamente com as propostas que pretendem implementar, se apresentam ao corpo eleitoral para a disputa em questão. As propostas formuladas em campanha revelarão quais matérias, em tese, nortearão a conduta no gabinete executivo.

Questionamo-nos se esse momento não tem sido negligenciado pela doutrina e pelas instituições jurídico-democráticas. O voto, no sistema representativo, constitui o mais alto momento de participação popular, pois é nele que se estabelece o liame direto que une 
os representantes eleitos para exercício do poder e os representados, o povo. É neste instante, com base nas informações e propostas apresentadas, que o eleitor conferirá legitimidade ao representante eleito para governar e legislar.

O próprio descrédito pelo qual passa a democracia, em muito decorrente da falta de confiabilidade dos representados de que seus interesses são tutelados pelos representantes, impõe que se busque uma alternativa que garanta maior efetividade à representação política. Há uma supervalorização do procedimento eleitoral e das pessoas escolhidas para governar e certo descaso e desregulamentação com a escolha das políticas públicas e ideias defendidas. As mazelas e dificuldades enfrentadas pelo regime democrático importam em analisar se o regime comporta aperfeiçoamentos, pois como teria certa vez asseverado Winston Churchill, a democracia é a pior forma de governo, com exceção de todos os demais regimes.

Por isso, causa certa estranheza a inexistência de qualquer vinculação jurídica efetiva entre o que o representante promete em campanha eleitoral e sua real conduta enquanto administrador, já desde os primeiros dias de governo. Tal situação autoriza um verdadeiro estelionato eleitoral, no qual o representante se vale de propostas populistas, adrede ciente de sua impossibilidade de implementação, apenas com o objetivo de obter os votos necessários a sua eleição, e ciente que não incorrerá em qualquer responsabilização jurídica. Em síntese, as propostas eleitorais passam a ser um verdadeiro jogo de cena, uma absoluta nulidade do ponto de vista jurídico e pura demagogia pelo espectro político.

Buscar uma solução para a falta de confiabilidade nas propostas eleitorais, que até hoje são tratadas como uma vicissitude da própria democracia e da política, não é tarefa simples. Muitos sustentarão que a essência democrática consiste exatamente neste embate de ideias, e que um povo, insatisfeito com um determinado político, negar-lhe-á o sufrágio na eleição seguinte, de tal sorte que a resposta para a questão por nós colocada deveria ser mantida na esfera política, sem repercussão na esfera jurídica.

Todavia, a velocidade com que as mudanças acontecem nos dias atuais não admite que se aguarde todo um mandato para a resposta popular nas urnas. Atualmente, os sistemas democráticos oferecem algumas soluções para a abreviação do mandato de parlamentares e governantes, como o impeachment, o voto de desconfiança nos regimes parlamentaristas, o afastamento judicial das funções, em caráter preliminar ou final, em decorrência da prática de crime ou ato de improbidade e, por fim, o recall, que consiste em o próprio povo retornar às urnas em que elegeu o governante para confirmar a revogação 
de seu mandato por escrutínio, como penalidade pelo descumprimento das promessas eleitorais ou, ao menos, grande ineficiência na tarefa de cumpri-las.

A democracia tem como natureza a soberania popular enquanto uma das razões do constitucionalismo é a limitação ao exercício do poder. Assim, é indispensável que o povo, titular do poder soberano, possa exercer alguma forma de controle em face dos representantes.

O voto manifestado na eleição representa o exato momento em que o povo, titular do poder nos regimes democráticos, transfere parcela desta competência ao representante, que em caráter legítimo, passa a exercer o poder político. No período pré-eleitoral, excetuada, é claro, a possibilidade de reeleição, o ainda candidato não detinha poder político representativo algum, e apenas com o resultado da eleição é que se lhe transmite o múnus público da representação. A imagem que parece representar bem esse procedimento é a de uma corrida de revezamento. É como se o povo, no processo eleitoral, corresse em direção dos representantes que desejam escolher, portando um bastão que contém as razões pelas quais o escolheu. E no exato instante em que o povo transmite o bastão ao representante, observadas as regras da corrida, é que o representante, investido do poder, dá sequência à corrida, não podendo invadir a raia alheia ou deixar cair o bastão, sob pena de desclassificação. Interferir fora dos limites legais em outros poderes corresponderia a invadir a raia alheia e deixar cair o bastão refletiria o não cumprimento com o que se espera do representante, tanto nos aspectos morais, que o tornariam indigno ao cargo, ou naquilo que se afaste da vontade dos eleitores, seja em relação às propostas formuladas em campanha ou na continuidade do diálogo durante a execução do mandato visando uma representação efetivamente responsiva.

É justo que a população que ontem elegeu um candidato com determinada plataforma política hoje veja exatamente o inverso daquilo que foi prometido e tenha que aguardar o término do embuste por quatro anos, sobretudo nos regimes que não possuem o instituto do recall? A retirada de um governante do poder, seja por meio do impeachment ou do recall, representa um processo muitas vezes lento e bastante prejudicial ao desenvolvimento de um país, com repercussões em todas às esferas do governo, especialmente a econômica, diante das incertezas que se abatem, consistindo em um verdadeiro solavanco na democracia e na governabilidade.

Por isso, mesmo nos sistemas que adotam o recall esta tese também nos parece falhar por ser uma espécie de tudo ou nada, não havendo um caminho intermediário, ou seja, só existem duas alternativas: o governante é apeado do poder antes do término do 
mandato ou cumpre todo o mandato, e dele não se pode exigir a observância de quaisquer das promessas neste período ou tampouco promover a quantificação do cumprimento das propostas.

Não seria interessante que houvesse um caminho intermediário?

Este trabalho buscará responder a essa questão, identificando se é possível buscar um ordenamento jurídico legal responsivo (responsiveness), que privilegie a transparência das propostas eleitorais, bem como a aferição quanto a seu cumprimento por meio de um órgão independente e a exequibilidade de algumas propostas de forma cogente.

Em síntese, a premissa da pesquisa consiste em analiar se existe uma crise democrática mundial em curso, algumas de suas causas e como poderiam ser aprimorados os mecanismos democráticos. O problema central da pesquisa, portanto, refere-se à ausência de instrumentos jurídicos aptos a conferir transparência e coercibilidade ao cumprimento das propostas eleitorais aos governantes eleitos.

A tutela do constitucional direito ao voto livre e igualitário implica em diversos fatores. Na seara passiva reflete o direito de lançar candidatura e de realizar campanha eleitoral, enquanto no aspecto ativo a liberdade de escolha dos candidatos e propostas, indene de influências indevidas externas como ameaça e coação. Nota-se que a liberdade na conduta de arregimentar eleitores não é ilimitada, e como tal, a tutela jurídica das propostas poderia trazer maior seriedade e responsabilidade aos proponentes, seja medidante instrumentos de controle administrativo, seja por meio de comando judicial.

Muitas são as razões pelas quais um eleitor escolhe um candidato. Pode ele se afeiçoar à agremiação do candidato, a suas propostas, sua experiência pessoal, sua origem, etnia ou até mesmo o simples fato de não ter seu nome envolvido com escândalos de corrupção. Qual critério tem maior ou menor influência na escolha do eleitor não será objeto de nossa análise no presente estudo, mas apenas a premissa de que as propostas eleitorais representam um liame que o candidato estabelece com o eleitor e que deve ultrapassar juridicamente a data da eleição, de forma que a conduta política do governante seja orientada em confluência com as propostas formuladas.

A hipótese consiste em identificar se é possível discriminar e tutelar a existência de direitos decorrente das proposições eleitorais realizadas, sem que evidentemente se engesse de forma indevida as esferas política e administrativa. Para tanto será necessário identificar o que pode ser exigível, como, quando e por quem. Em seguida, investigaremos potenciais escusas que podem ser apresentadas pelos governantes para o descumprimento das propostas. 
O desafio que propomos no presente trabalho é exatamente esse.

Seria viável que o próprio Poder Público, de forma isenta, ou seja, como atividade de Estado e não de governo, pudesse aferir o cumprimento das propostas para orientar a cidadania nos próximos pleitos, inclusive com a imposição de sanções legais em caso de descumprimento?

Além disso, analisaremos se o descumprimento de propostas eleitorais poderia ter consequências jurídicas previstas na lei, ou mesmo pelo próprio candidato que formulasse as propostas. Seria possível, então, estabelecer "contratos políticos", em que o candidato se comprometesse com determinadas propostas de tal sorte que do descumprimento adviessem consequências jurídicas com a imposição de penalidades ou a concessão de benefícios?

Por fim, nossa pesquisa conduzirá ao questionamento no sentido de identificar se seria possível que o Poder Judiciário, em relação a determinadas promessas e mediante prévia anuência do próprio candidato, não apenas constatasse a omissão da autoridade executiva, mas, substituindo-se ao governante, implementasse diretamente a medida. Nesta hipótese, o próprio candidato apontaria algumas de suas propostas de campanha como "elegíveis a direito", submetendo, por sua própria vontade, eventual descumprimento à tutela judicial direta.

Do ponto de vista metodológico, temos como pressuposto uma reflexão sobre a democracia, cruzando conceitos de ciência política e direito constitucional para avaliar o atual estado da representação democrática. O método dedutivo será utilizado para a pesquisa. Após analisar as bases teóricas para o tema, apresentamos o problema descumprimento doloso das promessas de campanha -, seguido da hipótese, de que o descumprimento é um fator de enfraquecimento democrático e que decorre da falta de mecanismos jurídicos de coercibilidade. Por fim, analisaremos a criação de instrumentos de accountability e coercibilidade como mecanismos de aprimorariamento da eficácia democrática.

Inicialmente, trataremos de situar o espaço epistemológico de nossa pesquisa, demarcando algumas balizas acerca da democracia, do Estado e da responsabilidade política. Contudo, tais abordagens não visam conferir algum caráter taxativo aos conceitos, mas apenas auxiliar na justificação dos alicerces que colocamos para o desenvolvimento da tese.

Um ponto bastante relevante consistirá em distinguir as situações que, embora, em tese, a proposta seja exequível e dentro da esfera de competência do candidato promitente, 
situações externas que poderiam tornar a proposta inexequível. Neste quadrante também se colocam as questões que não dependem exclusivamente do candidato promitente, como também do concurso de outros poderes ou órgãos. E, por fim, identificados os compromissos exequíveis, apontar o procedimento para a efetivação de tais políticas e direitos e a legitimidade daqueles que poderiam pleiteá-las. Tais instrumentos poderiam, talvez, se não restaurar a crença na democracia por parte do demos, ao menos reduzir o distanciamento entre o governantes e governados.

Não será objeto de nosso estudo a influência da mídia nos resultados eleitorais e tampouco o processo psicológico que conduz o eleitor a fazer suas escolhas. Nossa análise estará centrada em avaliar se é possível criar um reforço democrático, conferindo a determinadas propostas eleitorais e mediantes algumas condições, a existência de direito coletivo ao cumprimento da proposta ou ao menos a tomada de medidas na direção do cumprimento.

É inegável que existe certo grau de subjetivismo na escolha das premissas, o que não impede que se busque, ao máximo, a adoção do necessário rigor científico para o desenvolvimento do trabalho.

O trabalho está dividido da seguinte forma:

A primeira parte trata dos fundamentos teóricos para análise dos regimes democráticos, da representação política e das propostas eleitorais de campanha.

No primeiro capítulo tratamos do regime democrático, apresentando conceituação, um excerto histórico do regime, suas características, pressupostos, problemas e desafios. O objetivo é sedimentar na esfera política e constitucional as bases do regime no qual o elemento eleitoral, que mais diz respeito à pesquisa, se insere.

O segundo capítulo pretende discutir o vínculo político-eleitoral que se estabelece entre representantes e representados, assim como a maior aproximação do exercício do mandato com a vontade popular. Neste capítulo serão analisados também os mecanismos atualmente existentes de controle das propostas eleitorais no âmbito político e jurídico, especialmente se são eles suficientes ou comportam ampliação, tendo por fundamento inclusive o processo de juridificação do poder político e de uma democracia responsiva.

No terceiro capítulo, passamos a analisar especificamente as propostas eleitorais. Serão contemplados diferentes aspectos relacionados às campanhas eleitorais e propostas eleitorais, iniciando-se por uma classificação tipológica das propostas. Realizaremos um breve estudo comparado com o sistema de proposições eleitorais de outros países. Por fim, 
será avaliada a necessidade de sancionamento para os casos de descumprimento, chegando até as proposições que poderiam ser objeto de exigibilidade de prestação jurisdicional.

A Parte II do trabalho tratará das propostas de controle administrativo e judicial das proposições eleitorais.

O Capítulo 4 trata do controle administrativo das propostas, tendo por pressuposto o princípio da eficiência e a possibilidade de controle das políticas públicas. Serão analisadas algumas entidades de controle de propostas e políticas públicas, o dever do Estado de tutelar a veracidade das informações públicas, bem como delineamentos para a criação de um órgão de natureza pública responsável pela avaliação do cumprimento das propostas, que denominamos Agência de Verificação de Propostas Eleitorais. Ao final, esboçaremos um pequeno procedimento para análise das propostas, da apreciação de escusas pelo descumprimento por parte dos governantes e da imposição de sanções.

O Capítulo 5 principia tratando da promessa de cumprimento integral do mandato. Em seguida, passa-se a identificar os chamados "contratos políticos", concebidos pelo Prof. Hans Gersbach, em que o candidato se submete a consequências jurídicas, por ele próprio indicadas, pelo cumprimento ou não das propostas eleitorais. Por fim, ingressa-se na área mais sensível do trabalho, ao mesmo tempo mais inovadora e também igualmente mais sujeita a críticas. Trata-se da possibilidade de, na linha dos "contratos políticos", estabelecer cláusulas em que o próprio candidato submetesse o descumprimento, não apenas a consequências jurídicas a ele impostas, mas à abertura da via de tutela judicial coletiva que implicasse na substituição da figura do governante pelo Poder Judiciário para que a medida fosse implementada diretamente.

Ao buscar exemplos dos institutos e da problemática que envolve a presente tese, sem prejuízo de outros países, buscamos privilegiar Brasil e Espanha, porquanto se tratar de tese para a candidatura do doutoramento em regime de dupla titulação junto à Universidade de São Paulo (USP) e a Universidade de Salamanca (USAL). Especialmente pela atualidade do tema, por vezes menções são feitas a notícias colhidas da imprensa escrita e digital, com o escopo de dar suporte às propostas realizadas.

Como menção derradeira, vale consignar que o objetivo maior será o de lançar luzes para o momento eleitoral da apresentação das propostas de campanha, visando o aprimoramento do processo eleitoral e por consequência, do combalido regime democrático. Certamente, há um longo caminho a ser percorrido nesta linha, de tal sorte que a presente tese talvez represente apenas uma nova porta a ser aberta para a discussão do tema. 


\section{CONCLUSÃO}

O objetivo do presente trabalho consistiu em analisar as propostas eleitorais formuladas em campanha eleitoral, mais especialmente se elas ostentam algum grau de eficácia e quais seriam seus instrumentos de controle. A atualidade do tema guarda relação com o contemporânea estágio das democracias e as vicissitudes da representação política. Foi com esse escopo que buscamos dissecar o instituto das propostas eleitorais, identificando hipóteses de aprimoramento para que as propostas atuem como possível agente catalisador de incremento democrático, e não como mero instrumento de demagogia eleitoral.

A primeira conclusão que atingimos é no sentido de que a democracia sofre contemporaneamente uma grave crise gerando, não mais um flerte, mas até mesmo admiração de regimes autoritários passados por parte de parcela da cidadania, fortalecendo a ameça de uma terceira onda antidemocrática, de acordo com a classificação realizada por Przeworski. Embora as democracias mais maduras também sejam atingidas, as democracias mais jovens são as que mais sofrem os efeitos da crise de confiança. A insatisfação da cidadania com a democracia começa com a perda de confiança nas pessoas e nas estruturas que conformam o poder político. A defesa instransigente do regime democrático impõe a efetiva compreensão das razões pelas quais a cidadania tem apresentado menor apreço pela democracia. Dentre as várias causas que contribuem para a erosão democrática destacamos a crença de que a democracia está vinculada à crise de representatividade e às deficiências no desenvolvimento econômico.

A segunda conclusão refere-se à análise do vínculo político-eleitoral da representação política, em que detectamos a necessidade de uma maior aproximação da figura do exercício do mandato eletivo para cargos executivos com a vontade da população. A representação política necessita, portanto, de mecanismos de reinforcement democrático, instrumentos que confiram maior eficiência ao elemento dinâmico da representação. Esse caráter responsivo da democracia, já observado por meio dos instrumentos de democracia direta, ainda não encontra espaço estrutural naquela que é a ferramenta primordial dos regimes democráticos, a eleição. Afinal, é no escrutínio popular que o governante recebe a legitimidade para assumir a liderança executiva. 
Passamos, em seguida, à apreciação das propostas eleitorais de forma analítica, estabelecendo parâmetros teóricos e classificação das propostas. Chegamos, então, ao terceiro arremate, que se refere à constatação de que as propostas eleitorais formuladas durante o período de campanha eleitoral, na maior parte dos países democráticos, exceção feita parcialmente aos sistemas que adotam o voto programático, corresponde a um conjuto de proposições absolutamente inútil do ponto de vista jurídico, já que o cumprimento ou descumprimento não gera qualquer efeito, seja positivo ou negativo. As propostas são aceitas, portanto, como mero instrumento de bravata e demagogia eleitoral à disposição dos candidatos, que no máximo estão sujeitos à accountability vertical. E diante desta conclusão, que reputamos estar vinculada a um dos elementos de descrédito do regime democrático junto à cidadania, buscamos identificar instrumentos que pudessem oferecer algum controle das propostas pelo direito, bem como maior efetividade à sua implementação. As propostas eleitorais, até então praticamente ignoradas pelo direito, exceção feita à "forma", no que se refere a seu conteúdo poderiam se tornar mecanismos de maior valoração e de imposição cogente.

A quarta conclusão decorre da necessidade de avaliação quantitativa e qualitativa do cumprimento das propostas, representada pela sugestão de criação de ente de natureza pública que tenha por função exclusiva analisar, por meio de instrumentos técnicos, o efetivo cumprimento das proposições, gerando maior transparência e fornecendo melhores elementos para a cidadania para a escolha de representantes futuros. O órgão teria estrutura voltada à independência funcional e o produto do trabalho teria caráter informativo à cidadania para que se tenha um retrato bem acabado da confrontação entre as propostas eleitorais realizadas por um candidato e o que efetivamente foi realizado pelo representante quando eleito. No Capítulo 4 tratamos de sugerir a criação de uma autarquia de regime especial com essas características, que denominamos Agência de Verificação de Propostas Eleitorais, e que funcionaria tanto em âmbito federal como estadual. Além disso, diante de determinado grau de descumprimento das propostas, penalidades poderiam ser previstas em lei como, por exemplo, a vedação à reeleição.

A quinta conclusão compreende sugestão que se refere a viabilizar uma maior coercibilidade dos compromissos realizados em campanha, aumentando o rol de inelegibilidades, incluindo-se como hipótese, o descumprimento de compromissos específicos, como a promessa de cumprimento integral do cargo originário para o qual foi eleito. 
Em seguida, trazemos a possibilidade de criação de "contratos políticos", desenvolvidos originalmente por Hans Gersbach, em que se autorizaria que o candidatoproponente apresentasse determinados compromissos e consequências, positivas e negativas, para o caso de cumprimento e descumprimento. Ao eleger o candidato, a cidadania-aceitante, que estaria no outro polo desta figura assemelhada ao "contrato", aderiria à avença diante das proposições do candidato-proponente. Estes "contratos" passariam pela análise prévia de uma autoridade certificadora que cotejaria os compromissos com a constitucionalidade e legalidade das propostas, bem como com a possibilidade de aferição do cumprimento.

O quinto capítulo apresenta a derradeira conclusão, no sentido de que, em limitadas situações, o Poder Judiciário, por meio de tutela coletiva, poderia substituir a omissão da autoridade executiva, e prover diretamente o cumprimento das propostas, desde que o candidato voluntariamente submetesse tais propostas, no bojo de um contrato político, à referida situação de exigência judicial do conteúdo da proposta. Denominamos estes ajustes como "cláusulas elegíveis a direito" em que o próprio candidato voluntariamente afirma que o descumprimento de determinada proposta poderia dar ensejo à tutela judicial específica.

Tanto em sede de controle administrativo com em sede de controle de tutela judicial apresentamos algumas ideias relacionadas ao procedimento, com o intuito de avançar do campo das ideias para a efetiva materialização da teoria apresentada.

O fio condutor de todas as medidas sugeridas consiste em fomentar, de um lado a transparência, e de outro a vinculação contratual entre as propostas eleitorais, gerando maior accountability à cidadania, eficácia e reforço democrático ao sistema como um todo. Ao trilhar esse caminho, em várias oportunidades nos deparamos com todas as dificuldades inerentes à confluência entre as esferas da política e do direito.

Durante a pesquisa identificamos a complexidade inerente à análise das hipóteses de escusas de descumprimento e revisão dos compromissos, tanto para o controle administrativo como para o controle de tutela judicial.

A pesquisa que realizamos certamente traz muito mais perguntas do que respostas, sobretudo porque em alguns momentos, trilhamos caminhos que não foram ainda percorridos na interface entre a política e o direito.

Certamente, muitas são as vicissitudes que envolvem os incrementos democráticos, mas acreditamos ser indispensável lançar luzes sobre as propostas eleitorais, que possuem 
baixa densidade jurídica. Necessário, pois, que sejam criados instrumentos que valorizem efetiva e juridicamente as propostas eleitorais. 


\section{REFERÊNCIAS}

\section{Geral}

AARTS, Kees, THOMASSEN, Jacques e VAN HAM, Carolien. "Globalization, Representation, and Attitudes towards Democracy”. In: THOMASSEN, Jacques (editor) Elections and Democracy. Michigan: Oxford University Press, 2014.

ACHEN, Christopher. H. e BARTELS, Larry M. Democracy for realists Why Elections Do not Produce Responsive Government. Princeton: Princeton University Press, 2016, 390 p.

ANDRADE, Adriano; MASSON, Cleber; ANDRADE, Landolfo. Interesses Difusos e Coletivos. São Paulo: Método, $7^{\circ}$ ed. rev. atual. e ampl., 2017. 893 p.

ANDUIZA, Eva e BOSCH, Agustí. Comportamiento político y electoral. Barcelona: Ariel, 2000. 282 p.

AGESTA, Luis Sanchez. Princípios de Teoría Política. Madrid: Editora Nacional, 3. E.d., 1970. 540 p.

AGOSTINHO, Santo. A Cidade de Deus (contra os pagãos) (Trad. Oscar Paes Leme). Parte I, $2^{\text {a }}$ ed., Petrópolis: Editora Vozes, 2014. 535 p.

ARISTÓTELES. A Política (Trad. Roberto Leal Pereira). São Paulo: Martins Fontes, 1991.

BAUMAN, Zygmunt. Modernidade Líquida (Trad. Plínio Dentzien). Rio de Janeiro: Jorge Zahar Ed., 2001. 258 p.

BAUMGARTNER, J.; KADA, N. CHECKING EXECUTIVE POWER Presidential Impeachment in Comparative Perspective. Westport, CT: Praeger Publishers, 2003, Kindle Edition.

BERCOVICI, Gilberto. "Constituição e Política: uma relação difícil”. Lua Nova, São Paulo, $\mathrm{n}^{\circ}$ 61, 2004. Disponível em <http://www.scielo.br/pdf/ln/n61/a02n61.pdf>. Acesso em 31/01/2019.

BERLIN, Isaiah. Dos Conceptos de Libertad. El fin justifica los medios. Mi trayectoria intelectual (Traducción de Ángel Rivero). Madrid: Alianza Editorial, $2^{\circ}$ ed, 2014. 199 p. 
BERRINGTON, Hugh. "Dialogue of the deaf? The Élite and the Electorate in MidCentury Britain”. In: KAVANAGH, Dennis (org). Electoral Politics. Oxford: Clarendon Press, 1992. 71-96 pp.

BOBBIO, Norberto. Democracia e Segredo (Trad. Marco Aurélio Nogueira). São Paulo: Editora Unesp, 2015. 83 p.

O Futuro da Democracia (Trad. Marco Aurélio Nogueira). São

Paulo: Paz e Terra, 2000. 207 p.

BOWLER, Shaun e FARRELL, David M. "The Study of Election Campaigning". In: Electoral Strategies and Political Marketing (Orgs.). NY: The Macmillan Press Ltd, 1992. $245 \mathrm{p}$.

BUCCI, Maria Paula Dallari. Fundamentos para uma Teoria Jurídica das Políticas Públicas. São Paulo: Saraiva, 2013. 319 p.

BRANCO, Rilke Rithcliff Pierre. "Responsabilidades Político-Eleitorais, o Impeachment, a Improbidade e a Demagogia". Revista Temas Socio-Jurídicos. Bucamaranga, Colombia, v. 36, ed. 73, p. 141-152, julho-dezembro, 2017. Disponível em: <https://revistas.unab.edu.co/index.php/sociojuridico/article/view/2858/2376>.

BRENNAN, Jason. Against Democracy. Princeton: Princeton University Press, 2016. $288 \mathrm{p}$.

CAGGIANO, Monica Herman S. “A reeleição: tratamento constitucional (breves considerações)". Preleções Acadêmicas, CEPS - Centro de Estudos Políticos e Sociais de São Paulo, Caderno 1, 1997.

. "Democracia x constitucionalismo: um navio à deriva?" Cadernos de Pós-Graduação em Direito: estudos e documentos de trabalho / Comissão de PósGraduação da Faculdade de Direito da USP, São Paulo, n. 1, 2011. . Sistemas Eleitorais x Representação Política. São Paulo: Centro Gráfico do Senado Federal, 1987. . Oposição na Política. São Paulo: Angelotti, 1995.

CAPANO, Fernando Fabiani. "O Poder Judiciário e o movimento do constitucionalismo. Reflexões sobre o ativismo judicial no contexto da doutrina da separação dos poderes". 180 f. Dissertação (Mestrado) - Faculdade de Direito. Universidade Presbiteriana Mackenzie. São Paulo, 2011.

CARVALHO, Volgane Oliveira. Direitos Políticos no Brasil. O Eleitor no Século XXI. Curitiba: Juruá Editora, 2016. 150 p. 
CASTELLS, Manuel. Ruptura: a crise da democracia liberal. Trad. Joana Angélica d'Ávila Melo. Rio de Janeiro: Zahar, 2018. 150 p.

COMPARATO, Fabio Konder. A Afirmação Histórica dos Direitos Humanos. São Paulo: Saraiva, $6^{\circ}$ ed. rev. atual., 2008. 577 p.

Rumo à Justiça. São Paulo: Saraiva, 2. Ed., 2013.

CAMPILONGO, Celso Fernandes. Política, sistema jurídico e decisão judicial. São Paulo: Saraiva, $2^{\circ}$ ed., 2011. 195 p.

CONTI, José Maurício. Levando o Direito Financeiro a Sério. São Paulo: Blucher, 2016. 241 p.

COSTA NETO, José Wellington Bezerra da. Protagonismo Judicial - Novo Ativismo e Teoria Geral da Função Jurisdicional. São Paulo: Leud, 2017. 504 P.

DAHL, Robert A. A Constituição Norte-Americana é Democrática? (tradução de Vera Ribeiro, revisão técnica de Mario Brockmann Machado). Rio de Janeiro: FGV Editora, 2015. 192 p.

- Sobre a democracia (Trad. Beatriz Sidou). Brasília: Editora Universidade de Brasília, 2001. 230 p.

Poliarquia. (Trad. Celso Maduro Paciornick). São Paulo: Editora da Universidade de São Paulo, 2015.

DEBORD, Guy. A sociedade do espetáculo (Trad.: Estela dos Santos Abreu). Rio de Janeiro: Contraponto, 1997.

DÍAZ, Angel Eduardo Alvarez. "Los contenidos de la propaganda electoral y la protecction de la racionalidad politica del elector". In: MAGALLANES, Manuel Vicente (coord.) Propaganda Política Partidos y Sistema Electoral. Consejo Supremo Electoral, Colección del Cincuentenario 2. Caracas: Miguel Angel García e Hijo, s.r.l.: 1987.

DIDIER Jr, Fredie, ZANETI Jr. Hermes. Curso de Direito Processual Civil: processo coletivo. Salvador: Ed. JusPodivm, $11^{\mathrm{a} e d ., ~ r e f ., ~ a m p l . ~ e ~ a t u a l ., ~ 2017 . ~} 543$ p.

DINAMARCO, Cândido Rangel. Instituições de Direito Processual Civil: Volume III. São Paulo: Malheiros, $7^{\circ}$ ed. ver. e atual., 2017. 895 p.

DINIZ, Maria Helena. Curso de Direito Civil Brasileiro. São Paulo: Saraiva, $15^{\circ}$ ed. rev. v.7., 2001.562 p.

DI PIETRO, Maria Sylvia Zanella. Direito Administrativo. Rio de Janeiro: Forense, 31 e.d rev. atual e ampl., 2018. 1.109 p.

DUVERGER, Maurice. Institutions Politiques et Droit Constitutionnel - Les grands système politiques. Tomo I. Paris: Presses Universitaires de France, $12^{\circ}$ Ed., 1971. 
EGEA, Antonio Robles. "Líderes para uma Democracia de Calidad". In: EGEA, Antonio Robles; ORTEGA, Ramón Vargas-Machuca (eds). La Buena Democracia Chaves de su calidad. Granada: Editorial Universidad de Granada, 1997. 155-173 p.

ESPINOSA, Baruch de. Tratado Político (Trad. Intr. e notas Diogo Pires Aurélio). São Paulo: WMF Martins Fontes, 2009.

FERNANDÉZ, Andrés Rodríguez. "La Calidad En La Admnistración Pública". In: Evaluación y Calidad en las Organizaciones Públicas. Colección: Informes y Documentos. Madrid: Instituto Nacional de Administración Pública, 2000. 99-111 p.

FERNÁNDEZ, Santiago Delgado. "Ladrándole a la Luna" Validez del Proyecto Cosmopolita a la luz de la calidad democrática. In: EGEA, Antonio Robles; ORTEGA, Ramón Vargas-Machuca (eds). La Buena Democracia Chaves de su calidad. Granada: Editorial Universidad de Granada, 1997. 155-173 p.

FERREIRA FILHO, Manuel Gonçalves. A democracia no Limiar do Século XXI. São Paulo: Saraiva, 2001.

. Curso de direito constitucional. São Paulo: Saraiva, 35 ed., 2009. $398 \mathrm{p}$. . Sete Vezes Democracia. São Paulo: Convívio, 1977.

FILGUEIRAS, Fernando. Corrupção, Democracia e Legitimidade. Belo Horizonte: Editora UFMG, 2008.

FUKUYAMA, Francis. "Why is Democracy Performing So Poorly?" In: DIAMOND, L. e PLATTNER, M. F. (eds.) Democracy in Decline? Baltimore: Johns Hopkins University Press, 2016. 127 p.

GARCÍA-PELAYO, Manuel. Las Transformaciones del Estado Contemporáneo. Caracas: Fundación Manuel García-Pelayo, 2009.

GARGARELLA, Roberto. El derecho a la protesta: El primer derecho. Buenos Aires: Ad-Hoc, 2007. 265 p.

GASPARINI, Diogenes. Direito Administrativo. São Paulo: Saraiva, $4^{\circ}$ ed - rev. e ampl., 1995. $651 \mathrm{p}$.

GERSBACH, Hans. “Contractual Democracy”. Law \& Economics, n. 823, 2012. 823-851 p. Redesigning Democracy. Zürich: Springer, 2017. 248 p.

GILBERT, Martin. Winston Churchill: uma vida: Volume II. Trad. Elisa Nogueira. São Paulo: Leya Brasil, 2016, kindle edition. 
GISBERT, Antonio Bustos. Curso Básico de Hacienda Pública. Pamplona: Editorial Aranzadi, 4. E.d., 2017. 365 p.

GONZÁlEZ, María Holgado. El Programa de Gobierno y sus Sistemas de Control. Valencia: Tirant Lo Blanch, 2008. 454 p.

GROSS, Clarissa Piterman. "Fake News e Democracia: discutindo o status normativo do falso e a liberdade de expressão". In: RAIZ, Diogo (coord.) FAKE NEWS: a conexão entre a desinformação e o direito. São Paulo: Thomson Reuters Brasil, 2018. 154$174 \mathrm{p}$.

GUTMANN, Amy e THOMPSON, Dennis. Why Deliberative Democracy? United Kingdom: Princeton Univesity Press, 2004. 232 p.

HELD, David. Models of Democracy. Cambridge: Polity Press, $3^{\circ}$ Ed., 2017. 338 p.

HERNÁNDEZ, Juan Carlos González. Derecho Electoral Español. Normas y Procedimiento. Madrid: Editorial Tecnos S/A, 141 p.

HOLBROOK, Thomas M. Do Campaigns Matter? Contemporary American Politics. Thousand Oaks, California: Sage Publications, 1999. 178 p.

KANT, Immanuel. A Paz Perpétua. Trad. Marco Zingano. Porto Alegre: L\&PM Editores, 2011, versão kindle.

KAKUTANI, Michiko. A Morte da Verdade. Trad. André Czarnobai, Marcela Duarte. 1. Ed. Rio de Janeiro: Intrínseca, 2018. 270 p.

HUNTINGTON, Samuel. P. A Terceira Onda. São Paulo: Editora Ática, 1994. $335 \mathrm{p}$.

KELSEN, Hans. A Democracia.. São Paulo: Martins Fontes, $1^{\circ}$ ed, 1993, 392 p. Teoria Geral do Direito e do Estado. Tradução de Luís Carlos Borges. $3^{\circ}$ ed. São Paulo: Martins Fontes, 1998. 637 p.

LEITE, Glauco Costa. Corrupção Política: Mecanismos de Combate e Fatores Estruturantes no Sistema Jurídico Brasileiro. Belo Horizonte: Del Rey, 2016. 202 p. "O Processo de Impeachment como Instrumento de Combate à Corrupção". In: Alexandre Jorge Carneiro da Cunha Filho; Glaucio Roberto Brites de Araujo; Roberto Livianu; Ulisses Augusto Pascolati Junior. (Org.). 48 Visões sobre a corrupção. São Paulo: Quartier Latin, 1ed., 2016, p. 447-461.

. "Reeleição Presidencial no Brasil e seus Reflexos na Qualidade Democrática e no Combate à Corrupção”. In: Regina Tamami Hirose (org.) Carreiras 
Típicas de Estado: desafios e avanços na prevenção e no combate à corrupção. Belo Horizonte: Fórum: 2019. p. 135-145.

LEMBO, Cláudio. A pessoa: seus direitos. Barueri: Manole, 2007. p. 280. . "Faltou Algo Na Lei da Ficha Limpa". In: Monica Herman Caggiano. (org.). Ficha Limpa - Impacto nos tribunais: tensões e confrontos. São Paulo: Revista dos Tribunais, 2014. 117-120 p.

LEVITSKY, Steven e ZIBLATT, Daniel. Como as democracias morrem. Tradução Renato Aguiar. Rio de Janeiro: Zahar, 2018. 270 p.

LORENCINI, Bruno. Democracia Qualificada e Responsabilidade Política. São Paulo: LiberArs, 2018, p.81

LIJPHART, Arend. Patterns of Democracy: government forms and performance in thirty-six countries. $2^{\text {nd }}$ ed. New Heaven/London: Yale University Press, 2012. 348 p.

LINCOLN, Abraham. Lincoln's Gettysburg address at the National Cemetery at Gettysburg, Pennsylvania. Disponível em Library of Congress: $<$ https://cdn.loc.gov/service/rbc/lprbscsm/scsm0365/scsm0365.pdf. Acesso em 06/09/2017>.

LISOWSKI, Telma Rocha. Mandato Parlamentar \& Crise de Representatividade: instrumentos de perda e reforma do sistema. Curitiba: Juruá, 2018. 263 p.

LORENCINI, Bruno. Democracia qualificada e responsabilidade política. São Paulo: Liberars, 2018. 311p.

LUQUE, Teodoro. Márketing Político. Un análisis del intercambio político. Barcelona: Editorial Ariel, 1996. 227 p.

MARAVALL, José María. Las promesas políticas. Barcelona: Galaxia Gutemberg, 2013. 220 p.

MARQUES NETO, Floriano de Azevedo. "A Bipolaridade do Direito Administrativo e sua Superação”. In: ARAGÃO, Alexandre Santos de; MARQUES NETO, Floriano de Azevedo (Coord.) Direito Administrativo e seus novos paradigmas. Belo Horizonte: Fórum, 2018. 615 P.

MARSHALL, T. H. "Cidadania e Classe Social" In. Cidadania, classe social e status. Rio de Janeiro: Jorge Zahar Editores, 1967.

MARTÍNEZ I COMA, Ferran. ¿Por qué importan las campañas electorales? Colección <Monofrafías>, $\mathrm{n}^{\circ}$ 260. Centro de Investigaciones Sociológicas. Madrid: EFCA S.A., 2008. 288 p. 
MAXIMILIANO, Carlos. Comentários à Constituição Brasileira. V. II. Rio de Janeiro: Freitas Barros, $5^{\circ}$ ed. (atualizada), 1954.

MAZZILLI, Hugo Nigro. A defesa dos interesses difusos em juízo: meio ambiente, consumidor, patrimônio cultural, patrimônio público e outros interesses. São Paulo: Saraiva, 25 ed. rev. ampl. e atual., 2012. 912 p.

MEIRELLES, Hely Lopes. Direito Administrativo Brasileiro. São Paulo: Malheiros, $32^{\circ}$ ed., 2006. 826 p.

MELlo, Celso Antônio Bandeira de. Curso de Direito Administrativo. São Paulo: Malheiros, $34^{\mathrm{a}}$ ed., ref., e atual., 2019. 1179 p.

MENDES, Gilmar Ferreira e BRANCO, Paulo Gustavo Gonet. Curso de Direito Constitucional. São Paulo: Saraiva, 12 ed. rev. e atual., 2017. 1576 p.

MENEZES, Fernanda Montenegro de. "Marketing Político. Eleições Municipais de 2008”. In: LEMBO, Cláudio (Coord.); CAGGIANO, Monica Herman Salem (Org.). Comportamento Eleitoral. Barueri: Manole, 2010.

MODOLO, Artur Daniel Ramos. Hipertextualidade e relações dialógicas no gênero digital microblog político dos candidatos à presidêcia do Brasil nas eleições 2010. Dissertação de Mestrado Faculdade de Filosofia, Letras e Ciências Humanas, Universidade de São Paulo, 2011. 156p.

MOISÉS, José Alvaro. “A Confiança e os seus Efeitos sobre as Instituições Democráticas". In: MOISÉS, José Alvaro. (org.) Democracia e Confiança - Por que os Cidadãos Desconfiam das Instituições Públicas? São Paulo: Editora Universidade de São Paulo, 2010. 304 p.

. "Democracia e Desconfiança das Instituições Democráticas". In: MOISÉS, José Alvaro. (org.) Democracia e Confiança - Por que os Cidadãos Desconfiam das Instituições Públicas? São Paulo: Editora Universidade de São Paulo, 2010. 304 p.

MOLES Y PLAZA, Ramon J. Derecho y calidad: El régimen jurídico de la normatización técnica. Barcelona: Ariel, 2001. 322 p.

MORAES, Alexandre de. Direito constitucional. São Paulo: Atlas, $25^{\circ}$ ed., 2010. $922 \mathrm{p}$.

MORAES, Antonio Carlos Flores de. Legalidade, Eficiência e Controle da Administração Pública. Belo Horizonte: Fórum, 2007. 256 p.

MOREIRA NETO, Diogo de Figueiredo. Curso de Direito Administrativo: parte introdutória, parte geral e parte especial. Rio de Janeiro: Forense, $15^{\circ}$ ed. rev. ref. e atual., 2009. $759 \mathrm{p}$. 
MORLINO, Leonardo. "Teoria da Democratização, Qualidade da Democracia e Pesquisa de Opinião: Ainda em 'Mesas Separadas'”. In: MOISÉS, José Alvaro. (org.) Democracia e Confiança - Por que os Cidadãos Desconfiam das Instituições Públicas? São Paulo: Editora Universidade de São Paulo, 2010. 304 p.

MONTESQUIEU, Charles-Louis de Secondat. De l'esprit des loi. Paris: Vve Dabo, 1824.

MUNIZ, Carlos et al. “¿Están los políticos políticamente comprometidos?: Análisis del compromiso político 2.0 desarrollado por los candidatos a través de Facebook" .Cuadernos.info, Santiago, n. 39, p. 135-150, dic. 2016. Disponível em $<$ https://scielo.conicyt.cl/scielo.php?script=sci_arttext\&pid=S0719367X2016000200009\&lng=es\&nrm=iso>. Acesso em 21 de maio 2019. http://dx.doi.org/10.7764/cdi.39.970.

NEISSER, Fernando Gaspar. Crime e Mentira na Política. Belo Horizonte: Editora Forum, 2016. 295 p.

NICHOLS, Tom. The Death of Expertise. New York: Oxford University Press, 2017. $252 \mathrm{p}$.

NINO, Carlos Santiago. La constitución de la democracia deliberativa. Barcelona: Gedisa Editorial, 1997. 302 p.

NOHARA, Irene Patrícia. "Desafios da ciberdemocracia diante do fenômeno das fake news: regulação estatal em face dos perigos da desinformação". In: RAIZ, Diogo (coord.) FAKE NEWS: a conexão entre a desinformação e o direito. São Paulo: Thomson Reuters Brasil, 2018. 75-88 p.

O'DONNELL, Guillermo. "Nuevas Reflexiones acerca de la democracia delegativa (DD)". In: O’DONNELL, Guillermo; IAZZETTA, Osvaldo; QUIROGA, Hugo (coord.) Democracia delegativa. Buenos Aires: Prometeo Libros, 2011. 204 p.

ORTEGA, Ricardo Rivero; AGUILAR, Víctor Granda. Derecho Administrativo. Quito: Corporación Editora Nacional, 2017.252 p.

PEREZ, Marcos Augusto. "Controle da Discricionariedade Administrativa". In: PEREZ, Marcos Augusto; SOUZA, Rodrigo Pagani de (coord.) Controle da Administração Pública. Belo Horizonte: Fórum, 2017. Edição Kindle.

PÉREZ-LIÑÁN, Aníbal. Presidential Impeachment and the new political instability in Latin America. Cambridge, MA: Harvard University Press, 2007, Kindle Edition. 
PITKIN, Hanna Fenichel. El Concepto de Representacion. Madri: Imprenta Fareso, 1985. $289 \mathrm{p}$.

PLATÃO. A República. São Paulo: Edipro, 2001. 419 p.

POSNER, R. A. AN AFFAIR OF STATE - The Investigation, Impeachment and Trial of President Clinton. Cambridge, MA: Harvard University Press, 1999, Kindle Edition.

PRZEWORSKI, Adam. Democracia e mercado: reformas políticas e economicas no Leste Europeu e na America Latina. Rio de Janeiro: Relume-Dumara, 1994. 270 p.

RAIZ, Diogo. FAKE NEWS E ELEIÇÕES. In: RAIZ, Diogo (coord.) FAKE NEWS: a conexão entre a desinformação e o direito. São Paulo: Thomson Reuters Brasil, 2018. 105-129 p.

RANCIÈRE, JACQUES. O ódio à democracia. São Paulo: Boitempo, 2014, 125 p.

ROCHLIN, Nick. "Fake news: belief in post-truth", Library Hi Tech, Vol. 35 Issue: 3, pp.386-392, (2017). Disponível em: <https://doi.org/10.1108/LHT-03-2017-0062〉. Acesso em 18/05/2019.

ROUSSEAU, Jean-Jacques. Le Contrat Social. $1^{\circ}$ ed. Paris, 1851.

RUSSETT, Bruce. Controlling the Sword: The Democratic Governance of National Security, Cambridge, Harvard University Press, 1990. 201 p.

RUSSO, Alberto. Programma di Governo e Regime Parlamentar. Milão: Giuffré Editore, 1984. 223 p.

SALAMANCA, Felipe Rey. Voto Programático y Programas de Gobierno en Colombia. Bogotá: Universidad del Rosario, Facultad de Jurisprudencia, 2015. 234 p.

SARTORI, Giovanni. A Teoria da Democracia Revisitada. Vol. 2. São Paulo: Ática, 1994.

SCHUMPETER, Joseph A. Capitalismo, Socialismo e Democracia (Tradução Luiz Antônio Oliveira de Araújo). São Pulo: Editora Unesp, 2017. 582 p.

SIYÈS, Abade. Exposição Refletida dos Direitos do Homem e do Cidadão. Organização, estudo introdutório e tradução de Emerson Garcia. São Paulo: Atlas, 2015.

STEENBERGEN, Marco R. e LODGE, Milton. Process Matters: Cognitive Models of Candidate Evaluation. In: MACKUEN, B. Michael e RABINOWITZ, George (Orgs.). Electoral Democracy. Michigan: The University of Michigan Press, 2003. 336 p.

SOARES, Alessandro. A Democracia Direta no Constitucionalismo LatinoAmericano e Europeu: análise comparada de Venezuela, Equador. Brasil e Espanha. São Paulo: LiberArs, 2017. 570 p. 
SOUZA, Rodrigo Pagani de. "Em Busca de Uma Administração Pública de Resultados”. In: PEREZ, Marcos Augusto; SOUZA, Rodrigo Pagani de (coord.) Controle da Administração Pública. Belo Horizonte: Fórum, 2017. Edição Kindle.

STRECK, Lenio Luiz e MORAIS, José Luis Bolsan de. Ciência Política \& Teoria do Estado. 7. ed. Porto Alegre: Livraria do Advogado Editora, 2012, 224 p.

SUÁREZ, Francisco. De Legibus I De Natura Legis. Edición crítica bilíngue por Luciano Pereña. Corpus Hispanorum de Pace. Madrid: Consejo Superior de Investigaciones Científicas, 1971. Vol. XI, 359 p.

.. De Legibus (III 1-16) De Civili Potestate. Edición crítica bilíngue

por Luciano Pereña. Corpus Hispanorum de Pace. Madrid: Consejo Superior de Investigaciones Científicas, 1975. Vol. V, 404 p.

TELLO, Pilar Jimenez. Auditoría Universitaria y Calidad. La evaluación como conquista social ante la competencia universitaria global. Saarbrücken: VDM Verlag Dr. Müller, 2009. 469 p.

TOCQUEVILlE, Alexis. A Democracia na América: leis e costumes (Tradução de Eduardo Brandao). São Paulo: Martins Fontes, 2001.

URBINATI, Nadia. Representative Democracy. Chicago: University of Chicago Press, 2006. 328 p.

VILLEGAS, Mauricio Garcia. "Constitucionalismo Aspiracional: Derecho, Democracia y Cambio Social en América Latina”. Revista Análisis Politico. Bogota, v. 25, ed. 75, maio-agosto, 2012, pp. 89-110. Disponível em: <https://revistas.unal.edu.co/index.php/anpol/article/view/43508/44797>.

VITORIA, Francisco de. Relectio de Postestate Civili. Estudios sobre su Filosofía Política. Edición crítica por Jesús Cordero Pando. Corpus Hispanorum de Pace Segunda Serie. Madrid: Consejo Superior de Investigaciones Científicas, 2008. Vol. 15, 540 p.

\section{Sítios eletrônicos consultados}

Aplicativo Mudamos+. Disponível em: <https://www.mudamos.org/quem-somos>. Acesso em 05/04/2018.

Bancada Ativista. Disponível em: <https://bancadaativista.org/>. Acesso em $27 / 11 / 2019$. 
Canada Statistics Act 1985. Disponível em: <https://lawslois.justice.gc.ca/eng/acts/S-19/page-1.html?txthl=statistical+statistics\#s-4>. Acesso em 29/11/2019.

Congresso em foco. Disponível em: $<$ https://congressoemfoco.uol.com.br/eleicoes/maioria-dos-presidenciaveis-defendedesarmamento-veja-a-posicao-de-cada-um/>. Acesso em 13/03/219.

Consulta Polpular Anticorrupción en Colombia. Disponível em: <https://elecciones1.registraduria.gov.co/pre_cpa_20180826/consultas/html/inicio.html>. Acesso em 22/10/2018.

Eurostats. Disponível em: <https://ec.europa.eu/eurostat/statisticsexplained/index.php?title=Glossary:Eurostat $>$. Acesso em 22/11/2018.

Fórum de Segurança Pública. Disponível em: <http://www.forumseguranca.org.br/perfil/apresentacao/>. Acesso em: 19/02/2019.

Ibope Inteligência. Disponível em: <http://www.ibopeinteligencia.com/noticias-epesquisas/jair-bolsonaro-fica-numericamente-a-frente-mas-tecnicamente-empatado-commarina-silva-na-ausencia-de-lula-na-disputa-pela-presidencia-da-rep/>. Acesso em 26/10/2018.

Justiça Eleitoral. Disponível em: <http://www.justicaeleitoral.jus.br/desinformacao/>. Acesso em 09/12/2019.

"Mandata Juntas Codeputadas Estaduais". Disponível em: <https://www.juntascodeputadas.com.br>. Acesso em 16/05/2019.

Latinobarómetro. Disponível em: <http://www.latinobarometro.org/latOnline.jsp>. Acesso em 13/09/2019.

Programa do Partido Político Podemos (Espanha). Disponível em: <https://podemos.info/wp-content/uploads/2015/05/programa_marco_podemos.pdf>. Acesso em 25/09/2018.

Programa do Partido Político Vox (Espanha). Disponível em: <https://www.voxespana.es/wp-content/uploads/2015/12/Programa-electoral-VOX-26J.pdf>. Acesso em 29/10/2019.

Programa do Partido Político PSOE (Espanha). Disponível em: $<$ https://www.psoe.es/media-content/2019/04/PSOE-programa-electoral-eleccionesgenerales-28-de-abril-de-2019.pdf>. Acesso em 29/10/2019, 
Rede Nossa São Paulo. Disponível em: $\langle$ https://www.nossasaopaulo.org.br/portal/arquivos/metas-programa-doria.pdf $>$. Acesso em 25/09/2018.

Tribunal Superior Eleitoral. Disponível em: $<$ http://www.tse.jus.br/hotsites/esclarecimentos-informacoes-falsas-eleicoes-2018/>. Acesso em $09 / 12 / 2019$.

\section{Legislação e Jurisprudência}

ALEMANHA. Constituição de Weimar de 1919. Disponível em: <http://www.documentarchiv.de/wr/wrv.html\#ERSTER_ABSCHNITT>. Acesso em $06 / 02 / 2019$.

ARGENTINA. Código Electoral Nacional, Ley n ${ }^{\circ} 19.945$ de 14 de novembro de 1972. Disponível em: <https://bcn.gob.ar/uploads/Codigo-Electoral-Nacional-mayo2019.pdf>. Acesso em 28/11/2019.

BOLIVIA. Ley del Régimen Electoral, 30 de junio de 2010. Disponível em:< https://www.lexivox.org/norms/BO-L-N26.html>. Acesso em 28/11/2019.

BRASIL. Constituição Federal de 1988. Disponível em <http://www.planalto.gov.br/ccivil_03/Constituicao/Constituicao.htm>. Acesso em $27 / 11 / 2019$.

BRASIL. Constituição do Império do Brazil de 1824. Disponível em <http://www.planalto.gov.br/ccivil_03/Constituicao/Constituicao.htm>. Acesso em $27 / 11 / 2019$.

BRASIL. Congresso Nacional. Lei Complementar $n^{\circ}$ 135, de 4 de junho de 2010. Disponível em <http://www.planalto.gov.br/ccivil_03/leis/lcp/lcp135.htm>. Acesso em $27 / 11 / 2019$.

BRASIL. Congresso Nacional. Lei Federal n 9.096/95, de 19 de setembro de 1995 $\begin{array}{lllll}\text { (Lei } & \text { dos } & \text { Partidos } & \text { Políticos). } & \text { Disponível }\end{array}$ <http://www.planalto.gov.br/ccivil_03/leis/19096.htm>. Acesso em 27/11/2019.

BRASIL. Congresso Nacional. Lei Federal n 9.504/97, de 30 de setembro de 1997 (Lei das Eleições). Disponível em http://www.planalto.gov.br/ccivil_03/LEIS/L9504.htm. Acesso em 27/11/2019. 
BRASIL. Congresso Nacional. Lei Federal n 4.737/1965, de 15 de julho de 1965 (Código Eleitoral). $\quad$ Disponível em: http://www.planalto.gov.br/ccivil_03/leis/14737.htm>. Acesso em 28/11/219.

BRASIL. Congresso Nacional. Lei Complementar $n^{\circ}$ 64/1990, de 18 de maio de 1990. Disponível em: <http://www.planalto.gov.br/ccivil_03/leis/lcp/lcp64.htm>. Acesso em 28/11/219.

BRASIL. Congresso Nacional. Lei Federal n 13.165/2015, de 29 de setembro de 2015. Disponível em: <http://www.planalto.gov.br/ccivil_03/_ato20152018/2015/lei/113165.htm>. Acesso em 28/11/219.

BRASIL. Congresso Nacional. Lei Federal $n^{\circ}$ 12.527, de 18/11/2011 (Lei de Acesso à Informação. Disponível em: <http://www.planalto.gov.br/ccivil_03/_ato20112014/2011/lei/112527.htm>. Acesso em 28/11/2019.

BRASIL. Presidência da República. Decreto $n^{\circ} 76.664$, de 24 de novembro de 1975. Disponível em: <http://legis.senado.leg.br/norma/499304/publicacao/15644421>. Acesso em 29/11/2019.

BRASIL. Senado Federal. Projeto de Lei $n^{\circ}$ 229/2009. Disponível em: < https://www25.senado.leg.br/web/atividade/materias/-/materia/91341>. Acesso em 28/11/2019.

BRASIL. Supremo Tribunal Federal. ARE 639.337/SP, Rel. Min. Celso de Mello, DJ. 23.8.2011. Disponível em <www.stf.jus.br>. Acesso em 27/11/2019.

BRASIL. Supremo Tribunal Federal. RE 848826, Rel. Min. Roberto Barroso, julgado em 10/08/2016. Disponível em <www.stf.jus.br>. Acesso em 27/11/2019.

BRASIL. Supremo Tribunal Federal. ADI 5081, Rel. Min. Luís Roberto Barroso, julgada em 27/05/2015. Disponível em <www.stf.jus.br>. Acesso em 27/11/2019.

BRASIL. Supremo Tribunal Federal. RE 598099/MS, Rel. Min. Gilmar Mendes, julgada em 10/08/2011. Disponível em <www.stf.jus.br>. Acesso em 27/11/2019.

BRASIL. Tribunal de Justiça do Estado de São Paulo. Recurso Inominado 1015799-63.2017.8.26.0554, Rel. Glauco Costa Leite, julgado em 06/02/2018.

BRASIL. São Paulo. Lei Orgânica do Município de São Paulo. Disponível em: <https://www.prefeitura.sp.gov.br/cidade/secretarias/upload/educacao/cme/LOM.pdf>. Acesso em 28/11/2019.

BRASIL. São Paulo. Lei Estadual n 1.866, de 4 de dezembro de 1978. Disponível em:<https://www.al.sp.gov.br/repositorio/legislacao/lei/1978/lei-186604.12.1978.html>.Acesso em 29/11/2019. 
CHILE. Ley Organica Constitucional sobre Votaciones Populares y Escrutinios (Ley $\mathrm{n}^{\circ} 18.700 / 2016$ de 18 de outubro de 2016). Disponível em: $<$ https://www.leychile.cl/Navegar?idNorma=30082\&idVersion=2016-10-18>. Acesso em 28/11/2019.

COLOMBIA. Constitución Politica de Colombia. Disponível em: $<$ http://www.corteconstitucional.gov.co/inicio/Constitucion\%20politica\%20de\%20Colomb ia.pdf >. Acesso em 28/11/2019.

ESPANHA. Constitución Española de 1978. Disponível em: http://www.congreso.es/docu/constituciones/1978/1978_cd.pdf. Acesso em 05/02/2019.

ESPANHA. Constitución Española de 1812. Disponível em: < http://www.congreso.es/constitucion/ficheros/historicas/cons_1812.pdf >. Acesso em 06/02/2019.

ESPANHA. Ley $\mathrm{n}^{\circ}$ 12, de 9 de maio de 1989 (Ley de la Función Estadística Pública). Disponível em: <https://www.boe.es/eli/es/1/1989/05/09/12>. Acesso em $29 / 11 / 2019$

ESPANHA. Ley de Ordenación del Regimen Electoral General $n^{\circ}$ 5/1985. Disponível em: <http://www.juntaelectoralcentral.es/cs/jec/loreg>. Acesso em 25/01/2018.

EQUADOR. Ley Orgánica Electoral, Código de la Democracia, de 27 de abril de 2009. Disponível em: <http://aceproject.org/ero-en/regions/americas/EC/ecuador-leyorganica-electoral-codigo-de-la/>. Acesso em 28/11/2019.

ESTADOS UNIDOS. Title 18 US Code §599. Disponível em: <https://www.govinfo.gov/app/details/USCODE-2011-title18/USCODE-2011-title18partI-chap29-sec599>. Acesso em 28/11/2019.

MEXICO. Constitución de los Estados Unidos Mexicanos de 1917. Disponível em: $\langle$ https://archivos.juridicas.unam.mx/www/bjv/libros/6/2802/8.pdf $>$ Acesso em $06 / 02 / 2019$

MEXICO. da Ley General de Instituciones y Procedimientos Electorales. Disponível em: <https://www.te.gob.mx/consultareforma2014/node/5165>. Acesso em 28/11/2019.

PARAGUAI. Codigo Electoral Paraguayo (Lei n 834/96, de 17 de abril de 1996). Disponível em: < http://tsje.gov.py/static/ups/legislaciones/1996-ley-834.pdf>. Acesso em 28/11/2019. 
PERU. Ley de Oganizaciones Políticas (Lei n 28094 de 31 de outubro de 2003). Disponível em: <https://portal.jne.gob.pe/portal_documentos/files/fd6aadd2-0361-433b8cab-aef2a0c568b7.pdf>. Acesso em 28/11/2019.

PERU. Proyecto de Ley $n^{\circ}$ 1.313/2016 (Anteprojeto de Código Eleitoral Peruano) Disponível em: <http://portal.jne.gob.pe/portal_documentos/files/d408f47a-9367-460aa0e5-f0d84d7f524d.pdf>. Acesso em 28/11/2019.

VENEZUELA. Ley Orgánica de Procesos Electorales. Disponível em: < http://www4.cne.gob.ve/onpc/web/documentos/Leyes/Ley_Organica_de_los_Procesos_Ele ctorales.pdf>. Acesso em 28/11/2019.

\section{Notícias de periódicos}

“44\% dos eleitores se dizem pessimistas com eleição de 2018, diz Ibope". Portal G1. Disponível em: <https://g1.globo.com/politica/eleicoes/2018/noticia/44-dos-eleitoresse-dizem-pessimistas-com-eleicao-de-2018-diz-ibope.ghtml>. Acesso em 13/03/2018.

BOGHOSSIAN, Bruno. 'Não fui ao cartório', diz Serra sobre promessa de campanha em 2004. Estadão, 20/03/2012. Disponível em: $<$ http://politica.estadao.com.br/noticias/geral,nao-fui-ao-cartorio-diz-serra-sobre-promessade-campanha-em-2004,851093>. Acesso em 22/03/2018.

"Bolsonaro confirma que solicitou exoneração de diretor do Inpe". Disponível em: $<$ https://exame.abril.com.br/brasil/bolsonaro-confirma-que-solicitou-exoneracao-dediretor-do-inpe/>. Acesso em 21/10/2019.

"Comunidad de San Buenaventura pone al cepo a su alcalde Javier Delgado". El Deber. Santa Cruz de la Sierra, Bolívia. Disponível em: $<$ http://www.eldeber.com.bo/santacruz/Comunidad-de-San-Buenaventura-pone-al-cepo-asu-alcalde-Javier-Delgado-20180227-0001.html> . Acesso em 01/03/2018.

“Contrariando promessa, João Doria se lança ao governo de SP” Disponível em: $<$ https://catracalivre.com.br/geral/cidadania/indicacao/contrariando-promessa-joao-doriase-lanca-ao-governo-de-sp/>. Acesso em 22/03/2018.

"Negar Holocausto não é liberdade de expressão, decide corte europeia". Disponível em: <https://www.dw.com/pt-br/negar-holocausto-n\%C3\%A3o-\%C3\%A9liberdade-de-express\%C3\%A3o-decide-corte-europeia/a-50697201>. Acesso em: 07/10/2019. 
"No Twitter, Bolsonaro rebate críticas de vice Mourão ao $13^{\circ}$ salário". Disponível em: $\quad<$ https://exame.abril.com.br/brasil/no-twitter-bolsonaro-rebate-criticas-de-vicemourao-ao-13o-salario/>. Acesso em 28/02/2019.

"Negar Holocausto não é liberdade de expressão, decide corte europeia". Disponível em: <https://www.dw.com/pt-br/negar-holocausto-n\%C3\%A3o-\%C3\%A9liberdade-de-express\%C3\%A3o-decide-corte-europeia/a-50697201>. Acesso em: 07/10/2019.

“No Twitter, Bolsonaro rebate críticas de vice Mourão ao $13^{\circ}$ salário". Disponível em: $\quad$ <https://exame.abril.com.br/brasil/no-twitter-bolsonaro-rebate-criticas-de-vicemourao-ao-13o-salario/> . Acesso em 28/02/2019.

"Para 61\% dos brasileiros, posse de armas de fogo deve ser proibida, diz Datafolha". Disponível em: <https://g1.globo.com/politica/noticia/2018/12/31/para-61-dosbrasileiros-posse-de-armas-de-fogo-deve-ser-proibida-diz-datafolha.ghtml> . Acesso em 07/06/2019.

"Raggi: nel contratto multa da 150 mila euro e clausola dimissioni". Disponível em Corriere Della Sera: <https://www.corriere.it/politica/16_settembre_11/raggi-contrattomulta-150-mila-euro-clausola-dimissioni-209277f4-779a-11e6-a5b1-4fe0f4d. Acesso em $05 / 04 / 2018$.

"Trump says he 'never meant Mexico would write a check' for the wall". Disponível em: <https://www.cnbc.com/2019/01/10/trump-says-mexico-is-not-going-towrite-a-check-for-the-wall-contradicting-campaign-pledge.html>. Acesso em 14/02/2019.

“Zema diz que errou ao prometer que não pagaria salário a secretários estaduais" Disponível em: <https://politica.estadao.com.br/noticias/geral,zema-diz-que-errou-aoprometer-que-nao-pagaria-salario-a-secretarios-estaduais,70002871197>. Acesso em $13 / 09 / 2019$. 